Processo, Forense, 1989, pág.13; Athos Gusmão Carneiro, "Anotações Sobre o Mandado de Segurança Coletivo”, in AJURIS, 54, págs. 53-74.

6 RTJ $142 / 446-449$

7 RTJ 54/71 e RTJ 89/396

8 A propósito: J.J Calmon de Passos, in op.cit., págs, 12-13. 9 EDcl no MS no 197 , Rel. Min. Garcia Vieira, Primeir Seção, Ementário de Jurisprudência do STJ 4/167-168, em cuja ementa se diz que "A exemplo dos sindicatos e das associações, também os partidos políticos só podem impetrar mandado de segurança coletivo em assuntos integrantes de seus fins sociais em nome de filiados seus, quando devidamente autorizados pela Lei ou por seus quando da jetivos didn jetivos decid pâs a ele náo fliados ou interesses difusos e sim direito de natureza politica, como por exemplo os previstos nos artigos 14 a 16 da Constituiçáo Federal No mesmo sentido: ROMS 2423, Rel. Min. Luiz Vicen Cernicchiaro, $6^{\circ}$ Turma, DJ de 22.11.93, pág. 24974. $10 \mathrm{E}$ a orientação predominante no STJ, como se vê, g., do CC n ${ }^{\circ}$ 2.706-0-CE, Rel. Min. Demócrito Reinaldo, Primeira Seção, RSTJ 45/34, em cuja ementa está dito que "A ação civil pública $e$ as demais ações propostas com base na Lei $n^{\circ} 7.347$, de 24 de julho de 1985, devem ser ajuizadas no foro do local onde ocorreu o dano a que se refere seu artigo $2^{\circ}$. Se se trata de comarca em que não há juiz federal, será competente o juiz de direito, cabendo recurso ao Tribunal Regional Federal".No mesmo sentido: $\mathrm{CC} \mathrm{n}^{\circ}$ 2.230-RO, Rel. Min. Pádua Ribeiro, Primeira Seção, DJ de 28.05.93, pág. 10406. 11 Ada Pellegrini Grinover, comentando o art 95 do Colit. 95 do Codigo de Proterator vou que "A pretensão processual do autor coletivo, na ação de que trata o presente capítulo, é de natureza condenater o pedido". (in Codigo de Proteção e Defesa do Consumidor Comentado Pelos Autores do Anteprojeto, RJ Forense Universitária, $2^{2}$ ed., 1992, pág. 548
12 Ada Pellegrini Grinover, nos "Comentários .." citados, referindo-se à legitimação para a liquidação e execução, anotou que"... a liquidação e a execução serão necessariamente personalizadas e divisíveis. Promovidas que forem pelas vítimas e seus sucessores, estes estarão agindo na qualidade de legitimados ordinários, sendo individua o processo de liquidação e execução. E quando a liquidação e execução forem ajuizadas pelos entes enumerado no art. 82? A situação é diferente da que ocorre com a legitimação extraordinária à ação condenatória do art. 91 (...). Lá os legitimados agem no interesse alheio, mas em nome próprio, sendo indeterminados os beneficiários da condenação. Aqui, as pretensões à liquidac̃̃o e exroç̃̃̃o condenaçăo. Aqui, as pretensos à liquidação e execução da sentença serão necessariamente individualizadas: o caso surge como de representação, devendo os entes e pessoa enumerados no art. 82 agirem em nome das vítimas ou sucessores" (op.cit., pág. 553).

13 "O Ministério Público e a Defesa de Direitos Individuais Homogêneos", in Revista de Informação Legislativa a. 30, n.117, pág. 173; Revista Jurídica, v. 41, nº 189, pág 21.

14 "O interesse de grupos não se confunde com o interesse coletivo. O primeiro, mesmo contando com pluralidade de pessoas o objetivo é comum e limitado, ao passo que no segundo esta afeto a difusão do interesse, alcançando os integrantes da sociedade como um todo". (MS n ${ }^{\circ} 256$ DF, Rel. Min. Pedro Acioli, Primeira Seção. DJ de 04.06.90, pág. 5045. Assim: "Ação Civil Pública. Mensalidades escolares. Repasse do aumento dos professores. Ministério Público. Parte Ilegítima Não se cuidando de interesses difusos ou coletivos, mas de interesses individuis de um grupo de alunos de um determinato colid. ais de un grupo de alunos de um determinado colegio arasta-se a legitimidade do Ministera, RSTJ 54/306).

15 "Controle Jurisdicional da Administração Pública na 15 “Controle Jurisdicional da Administração Pública na
Nova Constituição", in RDP n ${ }^{\circ}$ 91, pág. 30 e ss, 1989, pág. 13;

\title{
Da Instituição do Pátrio Poder
}

\section{Carlos Silveira Noronha}

Professor de Teoria Geral do Processo, de Direito Processual Civil e de Direito Civil na Faculdade

\section{SUMÁRIO:}

1 - Conceito e evolução; 2 - Caracteres do pátrio poder; 3 - Os titulares do pátrio poder; 4 - $O$ pátrio poder quanto à pessoa dos filhos; 4.1 - O conceito de família e entes afins; 4.2 - $O$ dever de criação e educação; 4.3 - $O$ dever de guarda; 4.4-O dever de representação e de assistência; 4.5 - Outras prerrogativas dos pais quanto à pessoa dos filhos 5-O pátrio poder quanto aos direitos patrimoniais; 5.1 - Do usufruto legal; 6- Da suspensão do pátrio poder; 7 - Da destituição e extinção do poder paternal.

\section{Conceito e evolução}

Segundo o testemunho dos historiógrafos, a mais antiga versão do pátrio poder está na patria potestas, cultivada já em época pré-romana pelos hebreus, persas, gálatas $\mathrm{e}$ em geral pelos povos preclássicos consoante revelações de Aristóteles (Ethic Nicômaco, VIII, 10) e de César (De bello gallico, VI, 19), a que a generalidade dos romanistas se referem ${ }^{1}$. Mas é em Roma, na expressão de Gaio, que a patria potestas se aperfeiçoa e se institucionaliza definitivamente ${ }^{2}$.

E não discordam os tratadistas de que o acatado jurisconsulto clássico referia-se aos escravos, os quais, segundo o mesmo relata no parágrafo anterior de suas Institutas, também estavam sob a autoridade paternal, embora em condições menos vantajosas que os filii familias.

Dessa situação não dissente a doutrina romanista, isto é, de que filii e servi submetiam-se ao poder do pater familias. Mas, de igual modo, não se discute que na patriarcalidade havia distinções entre a potestas e o dominium relativamente ao escravo, pois o poder dominial para o último consubstancia-se numa relação de direito patrimonial, na qual o servus não era senão um objeto do direito, como qualquer coisa, enquanto perante a potestade era o mesmo figurante de uma relação jurídica que lhe reconhecia a condição humana ${ }^{3}$

Durante os primeiros séculos da idade romana, o poder paternal fez do chefe de família um sacerdote que presidia o culto familiar e um verdadeiro magistrado doméstico, que tomava as mais variadas decisões, sendo-lhe facultado executar sobre seus subordinados as penas mais rigorosas. Eram-lhe permitidos, v.g., o poder Vitae et necis, o de vendê-los a terceiros e o de abandoná-los a qualquer sorte, ou ainda, o de entregá-los como indenização noxae deditio. Esta situação imperou durante todo o período régio e, embora com moderações, no período republicano, quando o poder do chefe para determinar a morte do filho que estava sob sua potestade, devia contar com os parentes mais próximos ou com pessoas importantes, tais como senadores, consoante o relato de Aulus Gelius (Noctes Actices, V, 19) e o testemunho de autores da historiagrafia do $\mathrm{Di}$ reito 4 .

Todavia, a partir do Principado, foram relaxados muitos abusos do poder paternal, havendo Adriano, que subiu ao trono, no ano 117 d.C., expedido um edito que casti- 
gava um pater à pena de expatriação, por haver matado seu filho, culpável de adultério com a sogra. E já no final do segundo século da era cristã os poderes do pate familias estavam reduzidos a um modesto direito de correção, de tal modo que ensejou uma significativa máxima do jurisconsulto Marciano, inspirada na filosofia estóica: Nam, patria potestas in pietate debet, nun atrocitate consistere.

$\mathrm{Na}$ época de Antonino Caracala, no início do séculoi III da era cristã, foi declarad ilícita a venda dos filhos, havendo Diocleciano (285-305 d.C.) proibido qualque tipo de alienação dos filii, fosse mediante venda, doação ou empenho (garantia). $\mathrm{O}$ sucessor deste, Constantino (306-337), influenciado pela doutrina da Igreja Católica do Ocidente, decidiu que, em qualquer caso, todo aquele que tivesse mandado matar seu filho, seria castigado como parricida 5 .

Todos os componentes da família estavam unidos pelo vínculo da agnatio, ou parentesco civil, eis que nos primeiros tempos irrelevante tornou-se o vínculo da cognatio, ou parentesco consangüíneo. Esta veio adquirir real importância somente na primeira metade do século IV, com Constantino e sob as instâncias na Igreja, como se viu. Fi nalmente, com Justiniano (527-565 d.C.) desapareceu, de modo definitivo, a agnatio, restando suficiente a cognatio para estabelecer os vínculos de família 6 .

Destarte, na família romana incluiam-se pessoas estranhas à gênese familiar hoje concebida pelo direito moderno, no que se é levado a concluir que o conceito antigo de pátrio poder apresentava-se sobremodo discordante em relação ao atual, porquanto é no complexo familial que se apoia o de poder paternal. $E$ há entre nós tratadistas de tomo que advertem que, "comparando-se o pátrio poder na forma como se apresentava na antiga Roma, com o mesmo instituto na roupagem que hoje o reveste, nota-se uma tão profunda modificação em sua estrutura, que não se pode acreditar se trate da mesma instituição. Com efeito, a idéia que se tem é a de que o tempo provocou uma evolução tão radical em seu conteúdo, que afetou a própria natureza do poder paternal"7.

$\mathrm{Na}$ Idade Média, registra-se um conflito entre a orientação transmitida através da legislação justinianea que prevaleceu nos países de direito escrito, de um lado, e de outro, a linha do antigo direito germânico, muito mais branda e inspirada mais no interesse do filho do que o do pai, que vigeu nos países de direito costumeiro. Enquanto o Código Napoleão seguiu a linha germânica, o direito português das Ordenações seguiu a orientação romana, porém, já com os abrandamentos que o instituto sofreu através dos tempos. E é nesse sentido que se caracteriza o pátrio poder no direito moderno, onde se transformou em instituição de caráter protetivo das pessoas que, tendo vínculo consangüíneo ou civil com outrém que lhes deve proteção, encontrem-se impossibilitadas parcial ou totalmente para dirigir suas vidas e exercitar seus direitos 8

No âmbito do direito europeu-continental, a doutrina francesa, com base nas disposições do Código napoleônico, define o pátrio poder nos seguintes termos: "O poder paternal é o conjunto de poderes e de direitos que a lei confere ao pai e à mãe sobre a pessoa e bens de seus filhos, para lhes permitir satisfazer os próprios deveres"9.

Perante a doutrina pátria e na visão originariamente adotada pelo Código Civil de 1916 (art. 380), é a instituição do pátrio poder definida como "o complexo dos direitos que a lei confere ao pai sobre a pessoa e os is dos filhos". Com as modificações roduzidas na lei nacional, e especialmenom o chamado Estatuto da mulher casa(Lei $n^{\circ} 4121 / 62$ ), que modificou a redado precitado artigo 380, compete o pátrio ter aos pais, exercendo-o o marido com a aboração da mulher. É que, também sologicamente e filosoficamente, não se juscava que a mãe não tivesse iguais direitos everes. A lei acabou por reconhecê-los.

Esse conjunto de direitos, a que se refere :onceito acima, tem caráter tutelar e tetivo no direito moderno, visando mais tteresse do filho que, em razão de sua idaprecoce, necessita de um orientador ou tetor. Não mais se dirige à tutela de esses do pater, como no direito antigo. A oridade dos pais sobre os filhos não se este tão só de conteúdo jurídico, mas tam$\mathrm{n}$ de conteúdo moral e sociológico, pois manação de um poder que emerge de um cleo social, tal como é a família, ou uma idade familiar, hoje reconhecida pela nosCarta Política de 1988 (art. 226, $\int \mathbb{S} 3^{\circ} \mathrm{e}$ que abrange não só as uniões de fato esreis, como a comunidade formada por alquer dos pais e seus descendentes 10 . Para Pontes de Miranda, "o pátrio poder sderno é conjunto de direitos concedidos pai ou à mãe, a fim de que, graças a eles, ssa melhor desempenhar a sua missão de ardar, defender e educar os filhos, forman-os e robustecendo-os para a sociedade e a la" ou ainda "é o conjunto de direitos que ei concede ao pai, ou à mãe, sobre a pesa e bens do filho, até a maioridade, ou ıancipação desse, e de deveres em relação filho". A expressão "poder" tem o senti de exteriorização do querer e não o de posição ou violência.
Há que se entender que os direitos representam uma situação conseqüente aos deveres, mas é certo que no pátrio poder, como de resto nos demais direitos protetivos, a plêiade de deveres é de maior contingente que a dos direitos. Essa é a filosofia adotada pela lei pátria, recolhida mesmo de manifestação dos Tribunais, pois já anteriormente à edição do Código Civil, em julgado de 6 de novembro de 1909, o Tribunal de Justiça de São Paulo definia o pátrio poder como o conjunto de direitos e poderes que a lei concede aos pais, sobre a pessoa e bens dos filhos menores, para que possam cumprir os seus deveres, ocasião em que reputava conseqüentes aos deveres os direitos ${ }^{11}$.

\section{Caracteres do pátrio poder}

O pátrio poder qualifica-se como situação jurídica de natureza peculiar do ponto de vista técnico, tendo em vista constituir-se de um complexo de direitos e deveres atribuídos as personagens que nele atuam. Diante dessa perspectiva, apresenta características próprias que o distinguem de outros institutos.

Em primeiro lugar, não se desenvolve o poder paternal numa relação jurídica com direitos e obrigações correlatos. Embora a faculdade de agir do pai possa corresponder a um dever do filho, não se estabelece entre eles uma relação do tipo obrigacional, tal a que se forma entre credor e devedor, nem nele se pode enxergar, na sua feição moderna, um direito real sobre a pessoa do filho. Destarte, o pátrio poder constitui um munus imposto pelo Estado aos pais, que transcende o direito privado e se transfere para o âmbito do direito público. É o pátrio poder 
um direito-função, um poder-dever que se colocaria em posição intermédia entre o poder e o direito subjetivo ${ }^{12}$.

Uma outra característica do pátrio poder é a sua inalienabilidade e irrenunciabilidade. Tais situações decorrem da sua indisponibilidade, não podendo ser transferido pelos pais a outrém, nem abdicar do mesmo, dada a sua natureza pública, sujeit à tutela do Estado 13

A imprescritibilidade é outra característica decorrente das duas anteriores, eis que do pátrio poder não decaem os genitores pelo fato de deixar de exercê-lo. Na realidade, o pátrio poder só é retirado dos pais pela suspensão, perda ou destituição nos casos previstos em lei, nunca pela omissão dos titulares ativos ${ }^{14}$.

É de se registrar, ainda, a incompatibili dade do pátrio poder com a tutela. Esta só é cabível para menor que não tem pais vivo os quais tenham perdido o poder paterna por destituição ou dele tenham sido suspensos. Não pode haver menor sob tutela, salvo nos casos precitados, pois o instituto do pátrio poder, por ser mais amplo, absorve aquele $\mathrm{e}^{15}$

Por fim, caracteriza o instituto do pátrio poder o fato de ensejar, entre os personagens que dele participam, uma relação de autoridade e de sujeição, pois enquanto os genitores exercem uma atividade de comando, os filhos devem sujeitar-se ao dever de obediência ${ }^{16}$.

\section{Os titulares do pátrio poder}

No que diz com os sujeitos intervenientes na relação jurídica que se constitui pelo pátrio poder, cabe referir que nela interferem dois ou mais personagens que se agru- pam nos dois polos da relação: um ou mais indivíduos que se lançam no polo ativo, de um lado, e de outro, também um ou mais sujeitos que figuram no polo passivo. Destarte, dependendo da situação do núcleo familiar, a relação jurídica de pátrio poder poderá ser simples ou complexa. Simples, se o casal, ou o pai ou a mãe, individualmente, tiverem apenas um filho; complexa, na hipótese inversa, quando os consortes ou um deles individualmente tiver mais de um descendente. A complexidade, como se vê, opera-se sempre no polo passivo, eis que no polo ativo ela é ordinariamente simples, porquanto não pode haver mais de um pai ou mais de uma mãe relativamente ao mesmo filho.

$\mathrm{Na}$ conformidade da redação original do estatuto civil pátrio (art. 380), os titulares ativos do pátrio poder, que seguia o modelo francês expresso no Código Napoleão (art. 373), eram os pais, mas sendo o pai o chefe da família, competia-lhe, na vigência do casamento, exercitar os direitos pertinentes ao instituto, devendo ouvir a mãe em tudo o que se referisse ao interesse do filho. Tal situação não tinha o condão de absorver a personalidade da mulher, e nem, muito menos, aniquilar ou esgotar o direito da mesma de velar pelo bem estar do filho. A preferência conferida ao pai decorria da sua condição de chefe da família 17 .

Com as modioficações posteriores e especialmente com a edição do Estatuto da mulher Casada (Lei no ${ }^{\circ}$ 4.121/62), passaram a repartir a titularidade do poder paternal, marido e mulher, agora em sistema de comunidade e de exercício simultâneo do direito, "exercendo-o o marido com a colaboração da mulher". Também na sua versão atual repete a lei pátria o atual artigo 372 do estatuto francês, que agora tem redação mais suscinta do que o original ${ }^{18}$.
Segundo disposição final do artigo 380, :xercício do pátrio poder, que ordinariante é atuado pelos dois titulares, pode acentrar-se, no caso de perda ou suspen, de qualquer deles, na pessoa do outro, que também se repete o artigo 372-1 do idigo de França.

É dinâmico e ininterrupto o exercício do der de ambos os genitores sobre os filhos, modo que se não podem omitir em qualer dos deveres que a lei lhes atribui (arti; 384-391). É de se registrar não ser exauso o elenco de deveres enunciado na lei, is há inúmeros casos em que a jurispruncia tem caracterizado como omissão ou ;ídia de um ou de ambos os pais. E só para :ncionar um, traz-se à baila decisão do ibunal de Justiça de São Paulo, de 31.08,81, ı que aquele Pretório concentrou na pes$\imath$ da mãe o pátrio poder de filho menor, jo pai se omitira no desempenho do engo, ao decidir que "se o pai foi omisso na fesa dos direitos dos filhos, pode a mãe ercer o pátrio poder, sem quebra da chedo lar" (RT 533/115).

Há que se atentar que, apesar da inova$)$ introduzida no artigo 380, existe ainda ta preeminência do pai em relação à mãe exercício do poder pátrio, eis que no caso divergência de ambos, prevalece a deci) do cônjuge varão, cabendo à mulher ou nformar-se com a posição marital ou rerrer ao juiz. À manifestação judicial, devenecessariamente submeter o pai, no entto, a hipótese alvitrada na lei não registra 1l eficácia prática, porque a mulher, ante serspectiva de demanda com o marido ita freqüentemente abdicando dessa faculde, o fazendo, quase sempre, em prol da rmonia familiar, salvo, é evidente, se os :itos da deliberação errônea do pai causa- rem ao filho mal que transcenda o bem referido.

Afora a situação matrimonial fundada no casamento civil, que ainda é a regra, encontram-se agora reconhecidas pela nossa Carta Política (art. 226, $\$ \int 3^{\circ} \mathrm{e} 4^{\circ}$ ) outros módulos assemelhados à família, que desde muito conviviam no contexto social, mediante o beneplácito da jurisprudência, mas sem usufruir proteção plena da lei. São os casos do concubinato puro e a comunidade formada por qualquer dos pais e seus descendentes, a que a Lei Maior denominou "entidade familiar". É nosso entendimento de que no que pertine à relação entre pais e filhos, embora fora do casamento civil, são aplicáveis as normas de direito de família, e em tal circunstância a titularidade para o exercício do pátrio poder é do pai e da mãe em conjunto, não havendo, pois, discrepância, em confronto com os filhos havidos na união matrimonial tradicional, tutelada pela lei civil.

No caso de filhos havidos fora do casamento civil ou provenientes de entidade familiar, a titularidade para o exercício do poder paternal é de ambos os pais. Porém, na inexistência de convivência comum dos pais, exerce-o individualmente aquele que do filho tiver a guarda, já por razões de ordem prática, obviamente sem excluir a participação do outro genitor, quando oportuna ou necessária. Em tal sentido, já decidiu o Tribunal de Justiça de São Paulo, em julgado de 20.08.81 (Apelação $n^{\circ}$ 265.011), que "em benefício do menor, o pai adulterino pode pleitear a suspensão do pátrio poder exercido pela mãe, em face dos termos amplos do art. 394 do C.C.", cuidando-se especificamente de mau procedimento moral da genitora (RT. 558/71).

Até aqui, cuidou-se da titularidade para o exercício do pátrio poder dos pais relati- 
vamente aos filhos provenientes da consangüinidade. Mas, além desses, efetivamente os mais numerosos, há um não pouco expressivo contingente de filhos provenientes de parentesco civil, que se desligam dos ancestrais consangüíneos e se unem por parentesco civil aos adotantes, através dos institutos da adoção simples ou plena (C. Civil, art. 376). Estão tais menores sob o pátrio poder dos adotantes, que se erigem em titulares ativos para o exercício desse encargo familiar, em substituição aos pais consangüíneos.

Titulares passivos do pátrio poder são os filhos até a maioridade plena ou a emancipação, sejam, oriundos do casamento civil ou não. Leis tributárias, especialmente a do imposto sobre a renda, bem como previdenciárias, têm admitido a dependência econômica de filhos matriculados em cursos de ensino superior até 24 anos, o que não deixa de ser uma longa manus parcial do poder pátrio, em âmbito de proteção patrimonial.

\section{O pátrio poder quanto à pessoa dos filhos}

$\mathrm{Na}$ expressão de Savatier, o pátrio poder reúne em seu contexto um conjunto de direitos e deveres que a lei atribui ao pai e a mãe sobre a pessoa dos filhos, no direito moderno. Esses direitos ou deveres dizem imediatamente com a pessoa e a personalidade do menor, na sua transição de ente humano com compleição física e orgânica débil ou incompleta, com formação moral e psíquica ainda em desenvolvimento e com aspirações, ilusões e comportamentos, que são antes frutos da inconstância do que propriamente a revelação de rebeldia.
O menor é, por deficiências psíquicas e somáticas peculiares à sua idade, um ser carente e hipossuficiente no confronto com o mundo adulto, necessitando, por tal circunstância, que a medicina, a sociologia e o direito lhe ofereçam proteção, em razão de não possuir aptidões pessoais para suprílas ou assegurá-las pelo seu próprio agir, senão pela colaboração desprendida e altruística de outrem.

Diante dessa realidade, comum e inafastável na vida humana, cria a ordem jurídica instrumentos ou modos de suprimento das hipossuficiências vividas pelo menor em seu transitório estágio de vida, as quais sạ̃o de ordem biológica, psíquica, social e material. E se não satisfeitas no momento azado, tais deficiências poderão influir fatalmente no porvir da criança, resultando em deformidades raras vezes superáveis em sua vida adulta.

Por isso, é dever da pessoa sui iuris a quem a ordem jurídica atribuir o pátrio poder, velar não só pelos direitos fundamentais da criança ou adolescente, mas também implementar-lhe todas as necessidades surgidas em cada estágio de sua evolução biológica, através dos mecanismos da criação, guarda, alimentação, educação, repressão e assistência em geral.

\section{1 - O conceito de família e entes afins}

Concebendo a família ainda sob o módulo patriarcal, com as atenuações ditadas pela evolução sócio-jurídica emergente da época político-liberal em que foi editada, a nossa codificação seguiu os parâmetros das ordenações ligadas ao sistema romanogermânico, amparando-a em quatro ordens relações: a relação conjugal, o parentesco $r$ consangüinidade, o parentesco afim e o rentesco civil.

A relação conjugal é a célula-mater sobre ual descansa a relação de filiação, formanmarido e mulher o núcleo base em que se stenta a família natural, formada por pais ilhos, porque fundada na afinidade entre cônjuges e na consangüinidade entre es: e a prole. Conquanto não seja a relação njugal uma relação de sangue, acha-se maializada por uma fusão física, espiritual, stiva, solidária e duradoura, de modo a rmar o suporte psicológico e material da nília, cercando-a de uma relevância tal, no ando dos valores, que leva a doutrina a ntar-lhe, em sua defesa, um hino de lou$r$, ao qualificá-la como "núcleo fundamene irredutível das nações, manancial perede virtudes privadas e públicas, miniatudo Estado..., instituição milenária e unirsal que espíritos insensatos, desvairados serversos têm procurado dissolver, numa ogressiva relaxação, sacrificando ao oismo e aos vícios dos indivíduos os superres interesses da coletividade" 19 .

O parentesco é o vínculo que se estabeleentre pessoas que descendem uma da ou1 ou todas de um tronco comum, fundan1-se numa comunidade de gerações. $O$ prieiro tipo de relação parental constitui o rentesco em linha reta; o segundo, o lateral ou transversal, ou em linha oblía. Ambos formam o parentesco consaníneo.

O parentesco afim, que se fixa por deterinação da lei (C. Civil, art. 374), é o liame rídico que se opera entre um dos consortes os parentes consangüíneos do outro, sen, ilimitado na linha reta e restrito na lateral, até o segundo grau 20 . Este não ingra a família natural ou biológica.
$O$ parentesco civil resulta da adoção e constitui-se no vínculo jurídico que une o adotante e o adotado. Há dois tipos de adoção. A adoção simples, regulada pela lei comum (C. Civil, arts. 368-378), que se realiza por escritura pública; e a adoção plena, regulada pelo Estatuto da Criança e do Adolescente (Lei ${ }^{\circ} 8.069 / 90$ ), que se opera por sentença judicial. O filho passa, a partir do ato de adoção, a integrar-se no seio de uma família legítima, ou seja, aquela que se constitui segundo a lei.

Além do módulo familiar fundado no casamento civil ou no casamento religioso com efeitos civis, há que se considerar a existência de outros módulos afins à família, aos quais reconhece a lei a categoria de entidade familiar alinhando-os como entes equiparados à família tradicional milenarmente reconhecida e regulada pela ordem jurídica. Tais são o chamado concubinato puro, resultante da união estável entre homem e mulher, sem impedimentos para o casamento, e a comunidade formada por qualquer dos pais e seus descendentes, consoante as definições contidas nos $\int \mathbb{S} 3^{\circ}$ e $4^{\circ}$ do artigo $226 \mathrm{da}$ Constituição Federal, que expressamente as denomina entidade familiar.

Pela composição que apresentam estas, reunindo em seu núcleo os companheiros e a prole eventual, por um lado, ou a comunidade formada por um dos pais e seus descendentes, por outro, pode-se conceber que nestas duas figuras, admitidas pela sociedade $e$ reconhecidas pela ordem jurídica, contêmse os elementos necessários à formação de uma familia natural.

Acresça-se a essas, um terceiro ente que guarda estreita afinidade com a família clássica. É a chamada família substituta, instituição de notável significação social e humana, que a ordem jurídica pátria acaba de admi- 
tir, com a edição do Estatuto da Criança e do Adolescente (Lei ${ }^{\circ}{ }^{8.069 / 90}$, arts. 28

32). Entende-se por família substituta aquela que, como a própria denominação o diz, substitui a família natural, acolhendo menor que restar desprotegido, por extinção de sua família originária, ou em estado de abandono, com o objetivo de oferecer-lhe proteção familiar, social e jurídica, seja na condição de simples protegido, como na guarda e na tutela, seja na qualidade de filho, pelo vínculo civil da adoção plena.

Segundo a dita lei especial (art. 28), é através dos instrumentos da guarda, ou da tutela, ou da adoção plena que se constitui o ente chamado familia substituta, hábil a abrigar menor carente de família natural ou em estado de abandono ${ }^{21}$. Contrapõe-se, como se vê, a família substituta à família natural, pois enquanto esta é formada por vínculos consangüíneos que a unem fisiologicamente social e juridicamente, aquela se opera mediante os vínculos civis da guarda, ou da tutela, ou da adoção plena.

De tudo o que se acabou de examinar, há que se concluir, que a família tradicional, as entidades familiares e a família substituta constituem os sustentáculos em que basilarmente se apoia, se desenvolve e se perfectibiliza a instituição do pátrio poder

No sistema francês existe o Conseil de Famille (Code Civil, arts. 407-416) que se constitui após à morte de um ou de ambos os pais, com a finalidade de opinar acerca das atribuições do pátrio poder, na defesa dos interesses do menor, inclusive no que diz com a escolha do tutor, no caso de falecimento dos dois ou de apenas um dos genitores, havendo mais de um ascendente habilitado a exercer a tutela (Code Civil, art. 403). Este conselho é composto de quatro a seis membros, escolhidos entre os ascenden- tes, colaterais e demais pessoas ligadas por estreita amizade à família do menor, dele não participando nem o juiz, nem o tutor (Code Civil, art. 407). Segundo a doutrina, o Conselho de família francês tem as características de pessoa moral ${ }^{22}$. Tendo como fonte o sistema francês, a mesma instituição do Conselho de família (Familienrath) foi acolhido também pela codificação civil alemã ${ }^{23}$. No direito pátrio, embora fosse objeto de algumas cogitações genéricas, a dita instituição não tomou corpo. $O$ Conselho Tutelar, criado pelo Estatuto da Criança e do Adolescente Lei ${ }^{\circ} 8.069 / 90$, arts. 131 a 135 ) não tem similitude com o Conselho de Família.

\section{2 - Dever de criação e educação}

$\mathrm{Na}$ forma da própria expressão legal, ao pai e à mãe competem conjuntamente direitos e deveres em relação aos filhos menores. O dever de criação revela-se primordialmente um fato humano $e$ histórico que milenarmente antecede a tutela que veio a receber da normatividade jurídica. Para os adeptos e crentes da Igreja Católica, sua fonte original é de direito divino, estando inscrita na passagem do Gênesis, segundo a qual, Deus, após criar o homem e a mulher no paraíso terrestre, teria a ambos determinado: "Crescei e multiplicai-vos e enchei a terra". Mas também, não se deve deixar de considerar que o ato de criação do infante está estreitamente ligado ao fato da conservação da espécie e da perenização da gens familiar que integram os escopos da Humanidade.

De tal modo, revela-se o ato da criação do descendente, pelos pais, um acontecimento de profundo conteúdo humano, de expressão de amor e de interação social. O dever de criação, por se constituir numa conseqü- iia natural da paternidade e da maternidarecebe uma especial tutela da ordem juica, que o prefigura em primeiro lugar no nco de deveres dos genitores. Neste se in em todos os meios materiais necessário desenvolvimento do menor, tais os devede alimentação, de moradia, de preserva, da saúde, de vestuário, de acautelamento acidentes, de ensejar um convívio harmô :o e respeitoso, etc., de modo a propicia s filhos um crescimento saudável, visando hegar a uma vida adulta habilitada a dirisua pessoa e a administrar seus bens com Jficiência e segurança.

Pelo dever de educação, que está interado dever de criação, cumpre aos pais inicia filhos para a escolha de um modelo seritual ou de opção religiosa, que venha mplementar os anseios de espiritualidade e estão integrados em todo o ser humno, sentido do bem, do justo, do virtuoso, útil e do social.

$O$ dever de educação é antes um dever oral e um dever social, que a ordem jurídiacolheu e sancionou, por reconhecer que valores que dele promanam concorrem cisivamente para a integração do indivíto na sociedade e no Estado. Não admite a o descuido dos genitores com a instrução rmal dos filhos, pois o não cumprimento sse dever pode acarretar aos pais sanções vis, como a perda do pátrio poder (C. CiI, art. 395, I) e sanções penais, se tipificado sultar o crime de abandono material e inlectual do menor (C. Penal, arts. 244 e 246). Integra-se, de igual sorte, ao módulo lucativo do dever paternal e do castigar oderadamente o filho, no sentido de indi$r$-lhe os malefícios da ação incorreta e as ercês da correta conduta, embora a lei páia não a preveja expressamente. A doutri10 tem admitido, no que é secundada pela jurisprudência, devendo tal procedimento dos pais ser deveras cauteloso, para não caírem nas sanções civis (C. Civil, art. 395, I) ou na situação delituosa decorrente de maus tratos (C. Penal, art. 136) ${ }^{24}$.

Autores há que entendem estar implicitamente admitido na lei civil, a senso contrário do preceito contido no artigo 395 , o direito dos pais castigar moderadamente os filhos, como complementação do dever de educar $^{25}$.

Integra, por igual, o dever de educação atribuído aos pais, o de exigir obediência e respeito, porque estes constituem fatores de harmonià na convivência social, tanto no contexto familiar, quanto no complexo social externo (C. Civil, art. 384, VII).

Ainda na condução educacional dos filhos, é permitido aos titulares do pátrio poder exigir daqueles a prestação de serviços que sejam adequados à sua idade e estágio de desenvolvimento físico em que se encontrem (C. Civil, art. 384, I). No entanto, há que se observar que a lei trabalhista, no intuito de proteger o menor, veda-lhe o trabalho fora do lar até os 12 anos e o trabalho noturno até os 18 anos (C.L.T. arts. 403 e 404) ${ }^{26}$.

\section{3 - O dever de guarda}

O dever de guarda é um dos atributos mais importantes para o exercício do pátrio poder, pois 'é ao lado dos genitores, privando da atmosfera familiar, que os filhos estão mais eficientemente protegidos dos males físicos ou morais que venham afetar-lhes a vida biológica ou a consciência moral. Com tal proximidade, podem os pais exercer mais efetivamente o dever de vigilância sobre a conduta dos filhos no ambiente familiar $\mathrm{e}$ no convívio social externo, pois têm melho- 
res condições de aferir o comportamento do menor em tais circunstâncias.

$O$ internamento do menor, em regim de pensionato em estabelecimento de ensino, é considerado extensão do poder de guar$\mathrm{da}$, que pode ser delegado, nesse caso, com as cautelas legais. Nas hipóteses de separação ou divórcio dos genitores, o filho ficará na guarda de um deles, consoante o que se dispuser no processo judicial, de vez que o exercício do pátrio poder é comum a ambos os consortes (C. Civil, art. 381)

Ainda como decorrência do dever de guarda, a lei atribui aos pais o poder de reclamar a posse do menor de quem ilegalmente o detenha (C. Civil, art. 384, VI). Esta disposição da nossa lei civil encontra parâmetro no artigo 1. 632 do BGB alemão, que preceitua na tradução espanhola: El cuidado de la persona del hijo comprende el derecho de exigir la devolución del mismo de qualquiera que antijuridicamente se le detenga al padre 27 .

Discutiu-se algum tempo a respeito da ação judicial adequada à solução desse problema, mas a prática dos tribunais restou por definir ser a busca e apreensão o procedimento hábil para tal 28

\section{4 - O dever de representação e de assistência}

O atributo de capacidade das pessoas para a exercitação pessoal de atos jurídicos decorre do implemento de idade, de condições de saúde, ou de outros fatores específicos, tais a colação de grau em curso superior, o exercício do comércio com economia própria, o casamento civil, ou o instituto genérico da emancipação, segundo as disposições da teoria geral do direito civil (C. Civil, art. 84).
Para os menores sujeitos ao pátrio poder, todavia, o único fator determinante da incapacidade é o implemento de idade, levando-se em conta a incapacidade absoluta (C. Civil, art. $5^{\circ}$ ) e a incapacidade relativa (C. Civil, art. $6^{\circ}$ ). Deste modo os menores de 16 anos, por serem portadores de incapacidade absoluta, ficam alheios à realização dos atos jurídicos de que sejam titulares, sendo representados pelo pai ou pela mãe, enquanto que os menores com idades entre 16 e 21 anos cumpridos, já possuem alguma parcela de capacidade e por isso participam do ato jurídico, mas em razão de sua capacidade não ser ainda plena, são assistidos por qualquer dos genitores (C. Civil, art. 384, V)

\section{5 - Outras prerrogativas dos pais quanto à pessoa dos filhos}

No que respeita à autorização para casamento de menor sob o pátrio poder, compete aos titulares ativos desse direito/dever conceder ou negar anuência para o matrimônio do filho (C. Civil, art. 384, III). Todavia, quando se tratar de filho menor de 21 anos, oriundo de matrimônio civil, exige a lei o consentimento do pai e da mãe (C. Civil, art. 185). Havendo divergência entre os consortes, prevalecerá a vontade paterna, (C. Civil, art. 186) e, havendo denegação injusta, ao juiz caberá suprí-la (C. Civil, art. 188).

Se a lei assim dispõe, aludindo cautelas na autorização para casamento de menor sob o poder paternal, é porque tem em vista constituir o matrimônio um ato de importância transcendente na vida dos noveis consortes, cujos efeitos atinjam até a própria instituição do pátrio poder, devido à aquisição automática da emancipação do menor, pelo matrimônio (C. Civil, art. $9^{\circ}, \mathbb{1} 1^{\circ}$, II), re- ltando, destarte, a extinção do pátrio po$\mathrm{r}^{29}$

Por fim, dispõe a lei civil que dentre os :veres e direitos conferidos aos pais no exerzio do pátrio poder, há a considerar o que $\mathrm{z}$ com a nomeação de tutor para o menor, or testamento ou documento público auntico, no caso de um dos país não sobrevi:r à aquisição da maioridade pelo filho (C ivil, art. 384, IV)

Essa escolha dos pais, sobre quem deverá rercer o pátrio poder dos filhos após à sua orte, é uma faculdade especial que a lei onfere àqueles que têm a preocupação de em orientar os destinos de seus filhos. Tal culdade só é possível quando exercida por $\mathrm{m}$ dos genitores, diante da ausência por ualquer motivo do outro 30 .

\section{O pátrio poder quanto aos direitos patrimoniais dos filhos}

$\mathrm{Na}$ esfera patrimonial do instituto do átrio poder, há também uma plêiade de dizitos e deveres dos pais em relação aos fi10s, regulados pela ordem jurídica em cada aso específico. Nesse contexto, a primeir tribuição que a lei confere aos titulares atios do poder paternal é a administração dos ens dos filhos, sobre os quais gozam os prineiros de usufruto legal, que a lei considera nerente ao exercício da própria proteção raternal (C. Civil, art. 389).

Há que se entender que a administração los bens é deferida pela ordem jurídica aos aais, em razão da situação natural em que se ncontram, resultante de uma relação duraloura que os une a seus filhos, e que lhes nfunde confiança e segurança no desempetho do encargo. Ressalte-se, com efeito, que ss poderes conferidos aos pais são de mera ıdministração, na generalidade dos casos, tais os de zelar pela conservação dos bens, evitar-lhes o desgaste e o perecimento por fato de outrém, pagar-lhes impostos e taxas e outros cometimentos de pura e simples gestão. Em face disso, não é permitido aos administradores assumir obrigações que no futuro possam comprometer o patrimônio do menor e muito menos exercitar atos de disposição, bem como gravar de ônus reais os imóveis dos filhos. Não podem os pais, por igual, contrair, em nome do menor, obrigações que ultrapassem os limites da simples administração, salvo nos casos indicados na lei e mediante autorização judicial (C. Civil, art. 386)

Toda vez que os sujeitos ativos do pátrio poder tiverem necessidade de praticar qualquer ato que ultrapasse os limites da pura e simples administração e que esse se justifique, por resultar em benefício da prole, impõe a lei a consulta prévia ao Poder Judiciário (C. Civil, art. 386, parte final), mas por medida de cautela, tal procedimento deverá ser observado, sempre que o ato a ser praticado pelos pais situe-se nas fronteiras entre o ato de administração e o de disposição. Há legislações alienígenas que mais minudentemente destrinçam as hipóteses permitidas ou vedadas, como é o caso do sistema italiano, cujo artigo 320 do Código Civil expedido com o régio decreto $\mathrm{n}^{\circ} 262$, de 16 de março de 1942, milita nesse senti$\mathrm{do}^{31}$.

Pode ocorrer que, em determinadas situações, encontrem-se os pais, na administração dos bens dos filhos, em posição tal que faça colidirem os interesses destes com o daqueles. Em tais hipóteses, instala-se um conflito entre os titulares naturais da administração dos bens dos filhos e a pessoa destes. Para a solução desse impasse, háque serem chamados a intervir no ato ou no processo 
os órgãos tutelares da ordem pública estatal, longo, as utilidades e proveitos que ela enordinariamente o Ministro Público, bem cerra, sem alterar-lhe a substância ou mudarcomo a intervenção, por nomeação judicial, lhe o destino" 33 .

de curador especial para velar pelos interes- Perante o direito de família, há um tipo ses do menor (C. Civil, art. 387; CPC. art. especial de usufruto que incide sobre os bens $\left.9^{\circ}, \mathrm{I}\right)$.

No particular, o ordenamento civi pátrio seguiu os parâmetros do Código fran cês, que atualmente, com a reforma constant da Lei ${ }^{\circ} 75-617$, de 11.07 .75 , passou a disciplinar o assunto no artigo $389-6^{\circ}$; e também do Código italiano (art. 320), fonte direta da norma da mesma espécie inscrita na nossa codificação ${ }^{32}$.

Excluem-se da administração paternal os bens adquiridos pelo filho legítimo, antes do reconhecimento; os adquiridos pelo filho em serviço militar, de magistério, ou em qualquer outra função pública; os deixados ou doados ao filho, sob condição de não serem administrados pelos pais; e os bens que ao filho couberem na herança (art. 1.599), quando os pais forem excluídos da sucessão (art. 1.602). Nessas hipóteses, a lei exclui os bens do menor da administração e do usufruto paterno mais por razões morais do que propriamente por motivos de ordem patrimonial (C. Civil, art. 391).

\section{1 - Do usufruto legal}

O usufruto é direito real sobre coisa alheia (ius in re aliena), que é genericamente definido pela lei civil, segundo a qual "Constitui usufruto o direito real de fruir as utilidades e frutos de uma coisa, enquanto temporariamente destacado da propriedade" (C. Civil, art. 713), mas, para Lafayette, é "o direito real de retirar da coisa alheia, durante um certo período de tempo, mais ou menos especial de usufruto que incide sobre os bens
patrimoniais do filho sob o poder paternal, em favor dos pais, cujos fundamentos são expressamente pela própria lei fornecidos, ao declará-lo instituição "inerente ao exercício do pátrio poder" (C. Civil, art. 389). Ao pai e à mãe pertencem as utilidades, os frutos e rendimentos produzidos pelos bens dos filhos, situação que encontra sua fundamentação implícita na idéia de que as rendas originadas pelos bens do menor e recebidos pelos genitores compensam-se com as despesas que estes têm com a criação, educação, guarda e representação daquele, bem como com o elenco de providências e dispositivos armados para oferecer-lhe proteção. Se é verdade que aos pais incumbem, por dever legal, as despesas do filho, quando este não as possa atender, é também justo que os rendimentos produzidos por seus bens sejam utilizados pelos pais, para a cobertura dos ditos dispêndios.

$O$ usufruto dos bens dos filhos sob o pátrio poder tem suas origens no direito imperial romano, onde, ao tempo de Justiniano, havia quatro espécies de pecúlios: castrense, quase-castrense, adventício e profetício. $O$ instituto atual promana do pecúlio adventício, havendo se conservado no período do utroque ius e se disseminado nos costumes de vários povos. O Código Napoleão, admitiu o instituto como atributo da puissance paternalle e sob a denominação de juissance legale, que atualmente encontra-se definida no artigo 382 do Código $\mathrm{Ci}$ vil francês. Daí, espalhou-se pelas legislações ligadas ao sistema Civil law ou europeu-continental, a que se filia o nosso ${ }^{34}$.
Esse tipo de usufruto, em virtude de esar vinculado ao direito de família, não está ujeito a algumas regras gerais que o disciplilam no âmbito do direito das coisas, entre is quais, a caução a ser oferecida pelo usurutuário (art. 729), que aqui é dispensada, sersistindo, todavia, a hipoteca legal sobre ss bens dos ascendentes (C. Civil, art. 827, I), para assegurar ao filho não só a devolu;ão dos seus bens ao final da menoridade, :omo também o ressarcimento de eventuais Jrejuízos patrimoniais decorrentes de perda su deterioração dos mesmos, por culpa ou tolo do titular do pátrio poder ${ }^{35}$.

Além disso, esse usufruto especial não lepende de transcrição no registro de imó reis $^{36}$. Há que se salientar, ainda, que não sstão sujeitas à prestação de contas as renda sroduzidas pelos bens patrimoniais dos fihos e recebidas pelos titulares ativos do Játrio poder, porque estes as recebem como sóprias suas, por mandamento legal, salvo ie forem de alto valor, consoante já decidiu , Tribunal de Justiça de São Paulo, em Acórdão de 17.09.85, no sentido de que "O letentor do pátrio poder está isento da obrijação de prestar contas ao filho que atingiu a maioridade, salvo se os rendimentos forem de alto valor excedendo os gastos presumíveis da criação e educação do menor" (RT 603/ 189). Neste sentido é também o julgado constante da Revista dos Tribunais vol. 231, páక̧ina 295. A doutrina sobre o assunto não uniforme, existindo uma corrente que dispensa a prestação de contas ${ }^{37}$ e outra que a exige $^{38}$.

Excluem-se do usufruto legal, além dos bens que são excluídos também da administração paterna, referidos acima (item 5), mais os seguintes: a) os bens deixados ou doado ao filho com a exclusão do usufruto paterno (C. Civil, art. 390, I); b) os bens deixados ao filho, para fim certo e determinado (C. Civil, art. 390, II).

\section{6 - Da suspensão do pátrio poder}

Já se viu que o pátrio poder constitui-se num munus que o poder público tem o maior interesse em tutelar, por ser um fator de integração da família em prol da sociedade e do Estado. Por essa razão, é que se justifica a vigilância e a interferência estatal inclusive sobre fatos que se operam no foro interno da família, como ocorre com o exercício do pátrio poder pelos pais.

Efetivamente, verificando-se, por seu comportamento defeituoso, que os pais prejudicam os filhos, reage o ordenamento jurídico, aplicando àqueles sanções de menor ou de maior grau, que se consubstanciam, respectivamente, na suspensão ou na destituição do poder paternal. No primeiro caso, a pena é mais branda, pois é o exercício do encargo suspenso por tempo determinado, até que cessem as causas que lhe deram origem; no segundo, a penalização é mais exacerba$\mathrm{da}$, ocorrendo a destituição, por prazo indeterminado e, muitas vezes, em caráter definitivo.

A suspensão pode ocorrer por duas causas: má conduta do pai ou da mãe ou por fatos involuntários. A suspensão por decorrência de fatos involuntários opera-se: a) quando o titular do pátrio poder é interditado judicialmente; ou b) no caso de ausência, declarada por sentença 39 . A suspensão pode abranger a totalidade da prole, mas é muito comum acontecer que a causa determinante atinja somente um dos filhos e não os demais, caso em que a suspensão do pátrio poder será parcial. 
As causas determinantes da suspensão do poder paternal encontram-se genericamente enunciadas na lei civil e dizem respeito ao abuso de poder do pai ou da mãe para com o filho; falta aos deveres paternos; ou a delapidação dos bens dos filhos (C. Civil, art. 394), bem como pela condenação de qualquer dos pais, por sentença irrecorrível, por crime cuja pena exceda a 2 anos de prisão (C. Civil, art. 394, \único).

O Estatuto da criança e do Adolescente (Lei $\mathrm{n}^{\circ}$ 8.069, de 13.07.90), assimila as disposições do Código Civil, quanto aos deveres de sustento, guarda e educação dos filho menores, que dizem com os deveres recíprocos de ambos os consortes para com a prole acrescentando mais a "obrigação" de cumprir e fazer cumprir, no interesse dos menores, as determinações judiciais (Estatuto, art 22) e observando que "a falta ou carência de recursos materiais não constitui motivo suficiente para a perda ou suspensão do pátrio poder" (Estatuto, art. 23).

De tal modo, ressalvada a inovação quanto ao dever de cumprimento das determinações judiciais, que parece afirmar o óbvio, o Estatuto não cria outras causas de suspensão ou de destituição do pátrio poder. Inova apenas no que pertine as sanções e penalidades administrativas prevista no artigo 129 , entre as quais figura a de "advertência", imposta aos pais pelo descumprimento de seus deveres.

\section{Da destituição e extinção do pátrio poder}

Já se viu acima (item 6), que a suspensão do pátrio poder é a pena mais branda aplicável ao pai ou à mãe, enquanto a destituição é a pena mais grave, operando-se por sentença judicial. A destituição não era figura prevista na lei civil, mas era admitida pela jurisprudência (RF. 155/224 e RT. 138/203 e RT 169/650), mas agora acaba de ser contemplada pelo Estatuto da Criança e do Adolescente (artigo 129, X), para ser aplicada ao lado da suspensão, segundo seja a causa mais grave ou menos grave.

A destituição é uma medida imperativa que atinge a toda a prole e tende a ser permanente, embora possa ser o exercício do pátrio poder restabelecido, se desapareceu a causa que a determinou e, transcorridos 5 anos a contar da imposição d sanção, se o genitor punido provar a sua regeneração 40

São causas de destituição do poder paternal (C. Civil, art. 395), os fatos do pai ou da mãe que: a) castigar imoderadamente o filho; b) deixar em abandono o filho; c) praticar atos contrários à moral e aos bons costumes. Além dessas arroladas pela lei civil, a legislação trabalhista prescreve a perda do pátrio poder para o pai ou à mãe que permitir que o infante ou adolescente trabalhe em locais ou serviços perigosos, ou insalubres, ou prejudiciais à sua moralidade (C.L.T. art, 437 e $\int$ único).

Configura-se exaustivo esse elenco de causas determinantes da destituição dos pais do pátrio poder, não se podendo de outras cogitar. Além disso, é preciso que as ditas causas sejam contemporâneas ao pedido de destituição, consoante a jurisprudência, não podendo retroceder a fatos de passado distante, porque o seu estrépido e os seus efeitos maléficos podem já ter sido absorvidos ou superados socialmente ${ }^{41}$. Por outro lado, as causas de destituição arrolados acima poderão ensejar a pena suspensão, ao invés da destituição, tudo dependendo da maior ou menor gravidade, que restará à prudente discrição do juiz.
Esses casos de destituição, por seus efei, podem ainda redundar em hipóteses de inção do pátrio poder. É que a carga de zácia negativa que eles produzem na esfedos direitos do menor atingido torna-se etorquível, equiparando-se, desse modo, causas extintivas, emergentes de fatos e atos ndizentes com a ordem jurídica, não por vedados.

De qualquer maneira, as causas extintivas rmais da relação de poder paternal enconim-se também delineadas exaustivamente lei civil. São as seguintes (C. Civil, art. 2); a) a morte dos pais ou dos filhos; b) a ıancipação do menor, por qualquer das usas legais; c) a obtenção da maioridade, lo implemento de tempo; e d) pelo instito da adoção. A primeira e a terceira são usas involuntárias, pois independem da intade das pessoas intervenientes ativa $\mathrm{e}$ ssivamente na relação de pátrio poder; a gunda e a quarta, no entanto, constituemem atos voluntários, dependentes da vonde dos pais.

Há que se observar que essas causa tintivas do poder paternal distinguem-se, zanto ao aspecto da licitude, das causas que ısejam a destituição (art. 395), pois, enquan, as primeiras resultam de fatos ou atos sedientes à ordem jurídica, as últimas reltam de atos ou omissões contravenientes ordem legal.

\section{IBLIOGRAFIA}

ubry et Rau - Cours de Droit Civil Français, Tome I, aris, 1917

aio Mário da Silva Pereira - Instituições de Direito ivil, Vol. V, $8^{2}$ Edição Forense, Rio, 1991.
Clóvis Bevilaqua - Código Civil Comentado, Vol. II, Ed. Livraria Francisco Alves, Rio, 1917.

Eduardo Espinola - A Família no Direito Brasileiro, Edição Gazeta Judiciária, Rio, 1954

Emnanuel Vergé et Georges Rippert - Noveau Répertoire de Droit, Tome III, Ed Dalloz, Paris, 1949. Ennecerus, Kipp y Wolff - Tratado de Derecho Civil, trad. esp., Apendice - Código Civil Aleman (BGB), Bosch Casa Editorial, madrid, 1955.

Eugène Petit - Tratado Elemental de Derecho Romano, trad, esp Editorial Albatroz, Buenos Aires, 1970 Fustel de Coulanges - La Cité Antique, Édition Hachette, Paris, 1881

Gaetano Scherillo - Corso di Istituzioni di Diritto Romano, Edizione La Goliardica, Milano, sem data.

Gaio - Instituciones, versão bilingüe Latim - Espanhol, Editorial Civitas SA., Madrid, 1985.

Heinrich Lehmann - Derecho de Família, trad. espa nhola, Editorial Revista de Direito Privado, Madrid, 1953.

Henri Capitant - Les Grands Arrêts de la Jurisprudence Civile, Librairie Dalloz, Paris, 1950.

J. V. Castelo Branco Costa - O Pátrio Poder, Edição Universitária de Direito - Leued, São Paulo, 1978.

Lafayette Rodrigues Pereira - Direito das Coisas, Edição Freitas Bastos, Rio, 1943.

Louis Josserand - Cours de Droit Civil Positif Français, tome I, Paris, 1930.

Luiz da Cunha Gonçalves - Tratado de Direito Civil, Vol I Edição Max Limonad, São Paulo, 1955.

Marcel Planiol - Traité Élémentaire de Droit Civil, Tome I, Ed. Dalloz. Paris, 1908.

Maria Helena Diniz - Curso de Direito Civil Brasilero, $5^{\circ}$ Volume, Edição Saraiva, São Paulo 1985.

Orlando Gomes - Direito de Família, $7^{2}$ Edição Forense, Rio, 1992.

Paulo Lúcio Nogueira - Estatuto da Criança e do Adolescente comentado, Edição Saraiva, São Paulo, 1991. Pontes de Miranda - Tratado de Direito Privado, Tomo IX, Edição Borsoi, Rio, 1971.

René Savatier - Cours de Droit Civil, Tome I, Ed. Librairie Général de Droit et de Jurisprudence R. Pichon et R. Durand Auzias, Paris, 1947.

Silvio Rodrigues - Direito Civil - Direito de Família, volime 6, Edição Saraiva, São Paulo, 1991.

Vittorio Scialoja - Corso di Istituzioni di Diritto Romano, Ed. Anonima Romana Editoriale, Roma, 1934.

Washington de Barros Monteiro - Curso de Direito Civil - Direito de Família, Ed. Saraiva, São Paulo, 1983. 
12 Orlando Gomes - Direito de Família, no 229 , pp. $367-368,7^{\text {a }}$ Ed. Forense ( $4^{\mathrm{a}}$ tiragem), Rio, 1992.

1 Eugène Petit - Tratado Elemental de Derecho Romano, trad. esp., no ${ }^{\circ} 83$, pp. 143-144 e nora 2, Ed. Editorial Albatroz, Buenos Aires, 1970.

2 É de Gaio, vertida em língua Vernácula, a seguinte manifestação: “Também estão sob nossa potestas nossos filhos, isto é, os que procriamos dentro do matrimônio. Este direito é próprio dos cidadãos romanos, pois quase não existem povos que tenham um tal poder sobre seus filhos como o que nos temos, e isto é o que o consagrado Adriano declarou em edito que dirigiu aos que pediam para si e para seus filhos a cidadania romana. Não olvido, todavia, que a nação dos gálatas tenha acreditado que os filhos estão sob o poder dos pais" (Instituciones, 55, versão bilingüe latim-espanhol, Editorial Civitas SA., Madrid, 1985).

3 Vittorio Scialoja - Corso di Istituzioni di Diritto Romano, pp. 265-266, Ed. Anonima romana Editoriale, Roma, 1934.

4 Sobre 0 assunto, assim se manifesta Fustel de Coulanges: "Le père est le premier près du foyer; il l'allume et l'entretien; il en est le pontifice. Dans tous les actes religieux il remplit la plus haute function; il égorge la victime; la bouche prononce la formule de prière qui doit attirer sur lui et les siens la protection des dieux. La famile et le culte se perpétuent par lui; il représent à lui seul tonte la série des descendants. Sur lui repose le culte domestique" (la Cité Antique, p. 94 Édition Hachette, Paris, 1881.

Eugène Petit - Ob. cit., $\mathrm{n}^{\circ} 83$, pp. $145-147$ e notas 4 e 5 . 6 Sobre o tema, v. Gaetano Scherillo - Corso di Istituzioni di Diritto Romano, Vol. I, $\$ 13, \mathrm{n}^{\circ}$ s 29-31, pp. 180-201, Edizione La Goliardica, Milano, s/data. 7 Silvio Rodrigues - Direito Civil - Direito de Família, vol. 6; n ${ }^{\circ}$ 147. p. $355,17^{\text {a }}$ Edição Saraiva, São Paulo, 1991.

8 Silvio Rodrigues - Ob. cit., vol. 6, $\mathrm{n}^{\circ} 147$, pp. 357 358.

9 Emmanuel Vergé e Georges Rippert - Nouvea Répertoire de Droit, tome III, p. 667, Ed. Dalloz, Paris, 1949.

10 Sobre a conceituação de pátrio poder à luz da edição originária do Código Civil de 1916, v. Clóvis Bevilaqua - Código Civil Comentado, Vol. II, p. 360, Ed. Livraria Francisco Alves, Rio, 1917

11 Pontes de Miranda - Tratado de Direito Privado,

Tomo IX, \$ 974-976, pp. 105-113, Edição Borsoi, Rio de Janeiro, 1971 lia p. 270, Ed Saraiva, São Paulo, 1985.

14 Maria Helena Diniz - Ob. cit., Vol. $5^{\circ}$, p. 271

15 Washington de Barros Monteiro - Curso de Direito Civil - Direito de Família, p. 280, Ed. Saraiva, São Paulo, 1983

16 Maria Helena Diniz - Ob. cit., Vol. $5^{\circ}$, p. 271

17 Clóvis Bevilaqua - Código Civil Comentado, Vol II, p. 361, Edição Livraria Francisco Alves, Rio, 1917. 18 Emmanuel Vergé e Georges Rippert - Ob. cit., tomo III, p. 668. O artigo 372 do Código Civil francês tem a seguinte redação: "Art. 372. Pendant le mariage, les père et la mère exercent en commun leur autorité".

19 Luiz da Cunha Gonçalves - Tratado de Direito $\mathrm{Ci}_{\text {- }}$ vil, Vol. I, tomo 1, p. 243, Ed. Max Limonad, São Paulo, 1955.

20 Maria Helena Diniz - Ob. cit., Vol. $5^{\circ}$, pp. 244 e 251.

21 Sobre esse tema, v. Paulo Lucio Nogueira - Estatuto da Criança e do Adolescente Comentado, pp. 37 e segs., Edição Saraiva, São Paulo, 1991.

22 A respeito do "Conseil de famille" francês, v. René Savatier - Cours de Droit Civil, Tomo I, $\mathrm{n}^{\circ} \mathrm{s} 473$ a 477 pp. 241-243, $2^{\mathrm{a}}$ Édition, Librairie Général de Droit et de Jurisprudence R. Pichon et R. Durand - Auzias paris, 1947; Emmanuel Vergé e Georges Rippert - Op. cit., Tomo III, p. 669

23 A instituição do Conselho de Família foi regulada

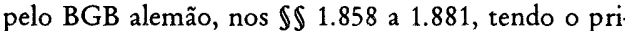
meiro, na versão espanhola, a seguinte redação: "1.858. Um Consejo de Familia debe ser instituido por el Tribunal de tutelas si el padre o la madre legitima del pupilo han ordenado la institución" (Ennecerus, Kipp y Wolff. Tratado de Derecho Civil, trad. esp., apéndiceCódigo Civil Aleman (BGB), pp. 381-385, Bosch - Casa Editorial, Madrid 1955; Heinrich Lehmann - Derecho de Família, trad. es., pp. 474-475, Editorial Revista de Derecho Privado, Madrid, 1953.

$24 \mathrm{~A}$ respeito do castigo moderado que os pais podem infligir aos filhos, v. Washington de Barros Monteiro Ob. cit., p. 278; Maria Helena Diniz - Ob. cit., vol. $5^{\circ}$, p. 273.

25 A opinião é de Pontes de Miranda - tratado, cit., tomo IX, $\$ 979$, p. 120

26 Silvio Rodrigues - Ob. cit., Vol. 6, nº 153, p. 365. innecerus, Kipp y Wolff - Tratado de Derecho Citrad. esp., Apêndice Código Civil Aleman (BGB), 37, Bosch - Casa Editorial, Madrid, 1955. illvio Rodrigues - Ob. cit., Vol. 6, n 153 , p. 364 Zlóvis Bevilaqua - Ob. cit., vol. II, p. 366. iduardo Espinola - A Família no Direito Civil Braro, $n^{\circ} 246$, pp. 457-458 e nota n ${ }^{\circ} 20$, Edição Gazeıdiciária, Rio, 1954.

duardo Espinola - A Família no Direito Civil Braro, $n^{\circ} 246$, pp. 457-458 e nota ${ }^{\circ} 20$, Edição Gazeıdiciária, Rio, 1954.

iduardo Espinola - Ob. cit., $\mathrm{n}^{\circ}$ 246, pp. 457-458 in 21.

afayette Rodrigues Pereira - Direito das Coisas, Vol. 303, Edição Freitas Bastos, Rio, 1943.

ubry et Rau - Cours de Droit Civil Français, tome pp. 119-120, Paris 1917; René Savatier - Cours de it Civil, Tomo I, no 228, pp. 126-127, Ed. R. Pichon . Durand-Auzias, Paris, 1947; Eduardo Espinola cit., $n^{\circ} 246$, pp. 457-459 e nota $n^{\circ} 23$.
35 Silvio Rodrigues - Ob. cit., Vol. 5, n 234 , pp. 385 387 e vol. 6, n ${ }^{\circ} 154$, pp. 365-367.

36 Pontes de Miranda - Tratado de Direito Privado tomo IX, $\mathbb{9} 980$, p. 125, Editor Borsoi, Rio, 1971 Orlando Gomes - Direito de Família, no 233 , pp. 375 376, $7^{2}$ Edição, Forense, Rio, 1991

37 Dispensam a prestação de contas do usufrutuário: Orlando Gómes - Direito de Família, no 233, p. 375,

$7^{2}$ Ed. Forense, Rio, 1992; Silvio Rodrigues - ob. cit., Vol. 6, $n^{\circ} 154$, p. 366; Maria Helena Diniz - Ob. cit., Vol. 5, p. 275.

38 Exige a prestação de contas do usufrutuário Caio Mário da Silva Pereira - Instituições de Direito Civil, Vol. V, n ${ }^{\circ} 418$, p. 239, $8^{\text {a }}$ Ed. Forense, Rio, 1991. 39 Orlando Gomes - Ob. cit., $\mathrm{n}^{\circ} 234$, pp. 376-377. 40 Maria Helena Diniz - Ob. cit., Vol. $5^{\circ}$, pp. 278 279.

41 Washington de Barros Monteiro, obra cit., pág. 286, Maria Helena Diniz - Ob. cit., Vol. 5, Direito de Família, pág. 278. 